\title{
OUTBREAKS AND NATURAL VIRAL EPIZOOTICS OF THE SATIN MOTH LEUCOMA SALICIS L. (LEPIDOPTERA: LYMANTRIIDAE)
}

\author{
Jadwiga Ziemnicka*
}

Institute of Plant Protection

Władysława Węgorka 20, 60-318 Poznań, Poland

Received: February 18, 2008

Accepted: February 21, 2008

\begin{abstract}
Long standing systematic observations on Leucoma salicis populations revealed numerous occurrences of outbreaks and natural viral epizootics. Number of insects appearing in outbreaks at peak density ranged from 450 to 3250 on 10 examined poplar trees (up to $2 \mathrm{~m}$ height). Abundance of virus within population of such a high density increased along with an increase of insect population. Populations with high density and high level of nucleopolyhedrovirus (LesaMNPV) and cypovirus did not last long and collapsed suddenly.

Outbreaks of the satin moth were favored by warm and humid conditions while warm and dry spring, summer months were conducive to viral epizootic. Most outbreaks happened in the years with mean temperatures of spring and summer months above $15^{\circ} \mathrm{C}$ and $50-60 \% \mathrm{RH}$ while, most epizootics were recorded at similar temperature conditions but lower $\mathrm{RH}$, i.e. $40-50 \%$.
\end{abstract}

Key words: Leucoma salicis L., outbreaks, epizootics, nucleopolyhedrovirus, cypovirus, bacteria, fungi, parasitoids

\section{INTRODUCTION}

The satin moth, Leucoma salicis L. is a destructive pest of willow trees (Salicaceae) causing severe damage in forest stands not only in several European countries but in some parts of Asia and both Americas as well. L. salicis is one of six pests from Lymantriidae family of economic importance (Grijpma 1989; Schoenherr 1989: Lipa and Kolk 1995; Lipa 1996). L. salicis outbreaks were observed on poplar trees in Belgium (Nef 1975), Italy (Arru 1975), Yugoslavia (Sidor 1976), Switzerland (Maksymov 1978), the Netherlands (Doom 1979), Bulgaria (Zakharieva 1983a), Romania (Teodorescu 1980),

\footnotetext{
*Corresponding address:

j.ziemnicka@ior.poznan.pl
} 
Spain (Huertos and Templado 1958; Ortiz and Templado 1973), Turkey (Cobanoglu 1992), and in Hungary (Abraham 1996). Large outbreaks were recorded in Siberia on European aspen (Populus tremula) (Kolomiec 1971; Dondikov 1974; Nikiforov 1979; Gromova 1980). In Kazakhstan the satin moth caused rigorous leaf damage leaving only main nerve untouched on willow trees (Salix caspica) (Marikovskij 1977) and in Japan on poplar trees (P. italica) and willows (S. babylonica) (Sirota et. al. 1976). In the 1920s the insects were accidentally introduced to America and established in hardwood forest stands (Furniss 1939; Wallner 1988; Schaefer 1989). In Central Europe the insects appear in one generation while in Southern Europe it is possible to see two or more generations throughout the year (Serafimovski 1972; Ortiz and Templado 1973; Cobanoglu 1992; Lipa and Głowacka 1996).

The satin moth is a common pest of poplar trees in Poland in all regions except for mountain areas. In the years 1953-1956 Schnaiderowa (1959) observed severe defoliation of the poplar species such as P. robusta and P. marylandica in central and eastern Poland. According to the author the poplar trees were more attractive food source than willows. At present the satin moth is mostly observed on P. nigra, P. balsamifera and P. italica (Ziemnicka 1976a, 1981). Based on the conducted survey P. nigra seemed to be the most luring food for the satin moth, also providing the best survival conditions. Feeding on other tree species, particularly on $P$. alba trees inhibited the development of the insects and increased their sensitivity to bacterial infection (Ziemnicka 1981; Avtzis 1990).

Annual defoliation of poplar trees resulting from the satin moth feeding does not present particular threat to poplar stands. The trees are capable to regenerate the assimilation system within several weeks. However, multiple-outbreaks of the insects present a serious threat because the tree ability of regeneration is rapidly decreased and it results in smaller annual growth and lower resistance to harsh climatic conditions, particularly severe frost. Weaker trees become more susceptible to other infections and pests as well. The dieback of the trees increases in intensity and at the end the trees die (Schnaiderowa 1959; Lejeune and Silver 1961; Clarke and Pardy 1971; Kolomiec 1971). The survey conducted in the Netherlands (Luitjes 1973) showed that annual damage caused by the satin moth intensive feeding decreased the annual tree growth by $34-80 \%$. Based on a calculated threshold it might be concluded that loss of foliage over $40 \%$ and presence of 16 caterpillars per $1 \mathrm{~m}^{3}$ of leaves are danger for a tree condition (Chen et al. 1990).

The causes of mass occurrence of the satin moth have not been well recognized yet. Some authors (Wagner and Leonard 1979) concluded that there is a relation between the pest density and food, and climatic conditions conducive to the insect development. The causes of a sudden decrease of the pest population have been fairly well determined. Harsh winters with temperatures below $-20^{\circ} \mathrm{C}$, parasitoids and pathogens (Reeks and Smith 1956; Schnaiderowa 1959; Lejeune and Silver 1961; Kailidis 1964; Jahn and Sinreich 1965; Clarke and Pardy 1971; Kolomiec 1971; Kuševska 1972; Wagner and Leonard 1980; Ziemnicka 1981) are considered the major factors affecting the insect populations.

Hymenoptera and Diptera play the important role among parasitoids as they can infect eggs, larvae and pupae. Telenomus nitidulus (Hymenoptera: Scelionidae) is the most effective egg parasite of the satin moth (Kolomiec 1971; Dondikov 1974; Nef 
1976; Grijpma et al. 1986; Zakharieva-Pentcheva and Georgijev 1997) while Apanteles rubipres and Rogas peluscens are larva parasites (Obozov 1968).

The satin moth might be infected with protozoans (Lipa and Ziemnicka 1996), the nematode Hexamermis albicans (Drea et al. 1977; Sidor et al. 1978), spiroplasma (Lipa et al. 1988; Lipa and Ziemnicka 1996), entomopathogenic fungi and viruses. Fungi and viruses occur frequently in the satin moth population. The fungus species Beauveria bassiana has been often associated with the viral epizootics but very rarely recognized as a main casual agent (Ziemnicka and Sosnowska 1996).

Nucleopolyhedrovirus (Baculoviridae) and cypovirus (=cytoplasmic polyhedrosis virus) CPV (Reoviridae) are the most important epizootic factors in the satin moth outbreaks. They both produce the polyhedral-shaped inclusion bodies inside a host body and the diseases caused by these viruses are called nucleopolyhedrosis.

Nucleopolyhedrovirus LesaMNPV is the most common pathogen and the main cause of collapses in outbreaks of the satin moth in natural populations (Orlovskaya 1968; Ziemnicka 1981; Chen 1984; Skatula 1985). Cypovirus despite its frequent occurrences in the satin moth populations is not a cause of epizootics. The epizootic caused by CPV was recorded only once in Austria in 1963 (Jahn and Sinreich 1965).

The objective of this research was to learn more about the cycles of outbreaks occurring in natural populations of the satin moth and identify the causes of their regular breaks down, and importance of environment with particular focus on climatic conditions.

\section{MATERIALS AND METHODS}

\section{Collection of insects}

Larvae of the satin moth (stage $\mathrm{L}_{2}-\mathrm{L}_{4}$ ) were collected at the end of May and beginning of June while the insects began feeding on lower parts of the trees. The individuals were captured from each of 10 selected trees up to $2 \mathrm{~m}$ height of a trunk, then counted and moved to laboratory in plastic containers. At first the larvae were reared in laboratory in glass vessels (10 1 each) covered with cheese clothes and fed with poplar leaves for 10 days. Food was supplemented daily.

\section{Health check of insects}

Health of the insects was checked with light microscope at magnification 400x and 1000x. Each dead insect was removed during that period. That quarantine allowed to recognize the insect with viral infections and other natural enemies of the satin moth.

After 10 days the remaining healthy insects were treated with ether and chloroform. All individuals were identified if there were less than 100 in a group; otherwise a sample of 100 was selected for further study.

Viruses were defined using wet mount, permanent tissue slides stained with carbol fuchsin (Ĕvlachova and Švecova 1964) and identified with a microscope (Ziemnicka 1981).

Presence of entomopathogenic fungi was checked microscopically using wet mount slides of insect tissues. If any were present the slides were placed on moisten filter paper in a Petri dish for several days at $20-25^{\circ} \mathrm{C}$ until sporulation occurred. The fungal species were identified based on macro and micro features of mycelium growing on Sabouraud medium (Gams 1971; De Hoog 1972; Samson 1974). 
Identification of entomopathogenic bacteria was done based on Gram staining and morphology of vegetative cells and endospores after incubation on a solid nutritional agar (Harrigan and McCance 1966).

The protozoans were recognized using wet mount slides stained with $0.2 \%$ Giemsa stain (Lipa 1967).

Macro and micro identification techniques were applied to characterized nematodes from the family Mermithidae. The species were distinguished based on the morphological features (Poinar 1975).

\section{Meteorological date}

Meteorological data were obtained from the Institute of Meteorology and Water Management in Warsaw.

\section{RESULTS}

Development of the satin moth was monitored from mid-May until the end of August. The larvae at stage $\mathrm{L}_{2}$ left their overwintering shelters at the end of May, which is typical of climatic conditions in Poland. The most active were the larvae at stage $\mathrm{L}_{4^{\prime}}$ they represented the greatest threat to the trees. At the end of June and beginning of July the larvae at stage $\mathrm{L}_{6}$ were getting ready to enter the pupal stage.

The insects developed at different rate despite the outbreak site. Simultaneously there were present larvae feeding on leaves or entering the pupal stage, mature pupae and on occasion single butterflies.

Most butterflies were recorded in mid-July. Larvae hatching were observed for two weeks starting at the beginning of August. The young larvae $\left(\mathrm{L}_{1}\right)$ searching for food moved toward top of trees and stayed there for few days, and ate voraciously. They were able to defoliate trees of all leaves after which they turned into stage $\mathrm{L}_{2}$. As far as a development of the satin moth is considered under Polish climatic conditions, the larvae at stages $\mathrm{L}_{3}-\mathrm{L}_{6}$ are called the spring-summer generation and at stage $\mathrm{L}_{2}$ the overwintering one.

Three centers were selected from all examined satin moth outbreak sites in Poland; Wielkopolska region (Kórnik), Łódź region (Kutno) and Śląsk region (Katowice). The pests were destroying the trees of $P$. nigra and $P$. italica growing on roadsides- population "Kórnik", near train tracks-population "Kutno" and in downtown-population "Katowice". The outbreak sites and epizootic centers were evaluated based on a model threshold describing number of pests and percent of infected insects. Values above the thresholds indicated an increase of either population density or higher viral disease incidence within the insect population. The thresholds were following 5 larvae/trunk up to $2 \mathrm{~m}$ and $5 \%$ infected insects.

\section{DYNAMICS AND HEALTHINESS OF INSECTS IN “KÓRNIK” POPULATION}

Continuous monitoring of population dynamics of the satin moth in Kórnik area was conducted for nineteen years (1972-1990) from May $18^{\text {th }}$ to $31^{\text {st }}$ (Fig. 1) on the poplar trees ( $P$. nigra) growing on roadsides. Results from observations conducted during first year showed a decline of the insect population density (depression phase; 


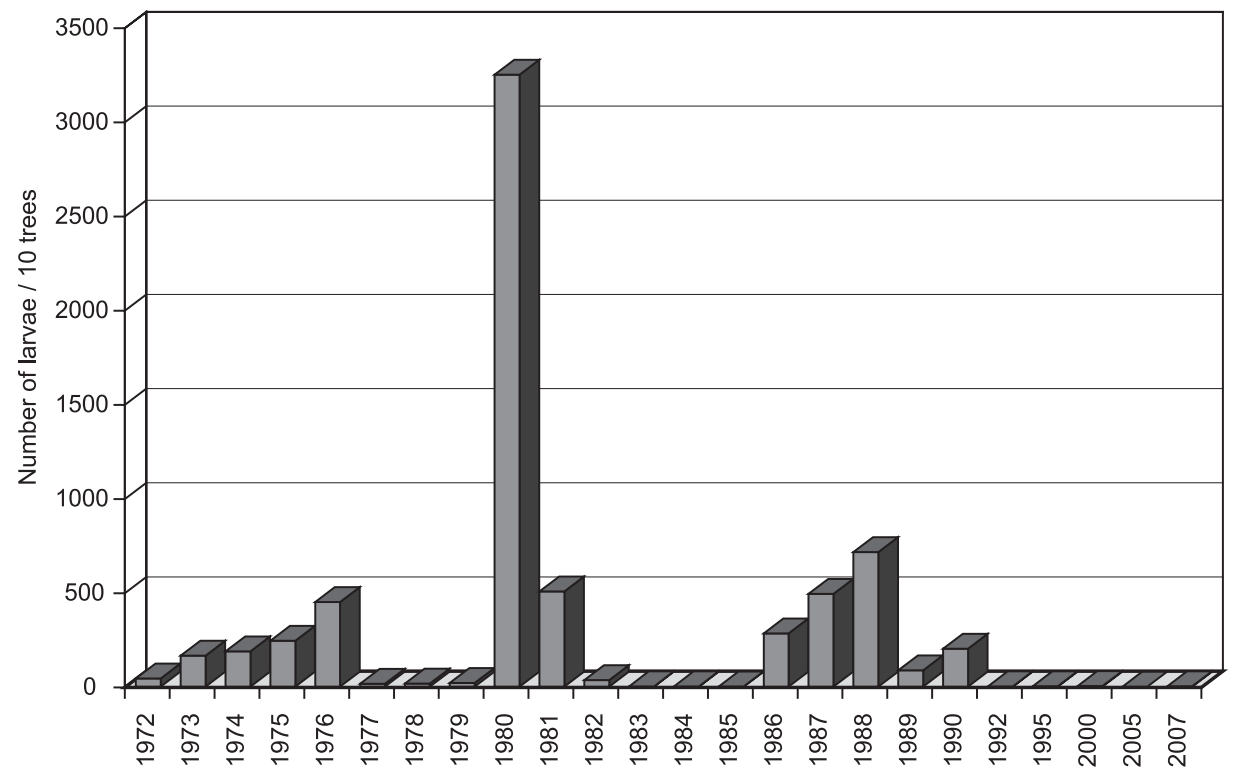

Fig. 1. Population dynamic of the satin moth (L. salicis) - "Kórnik"

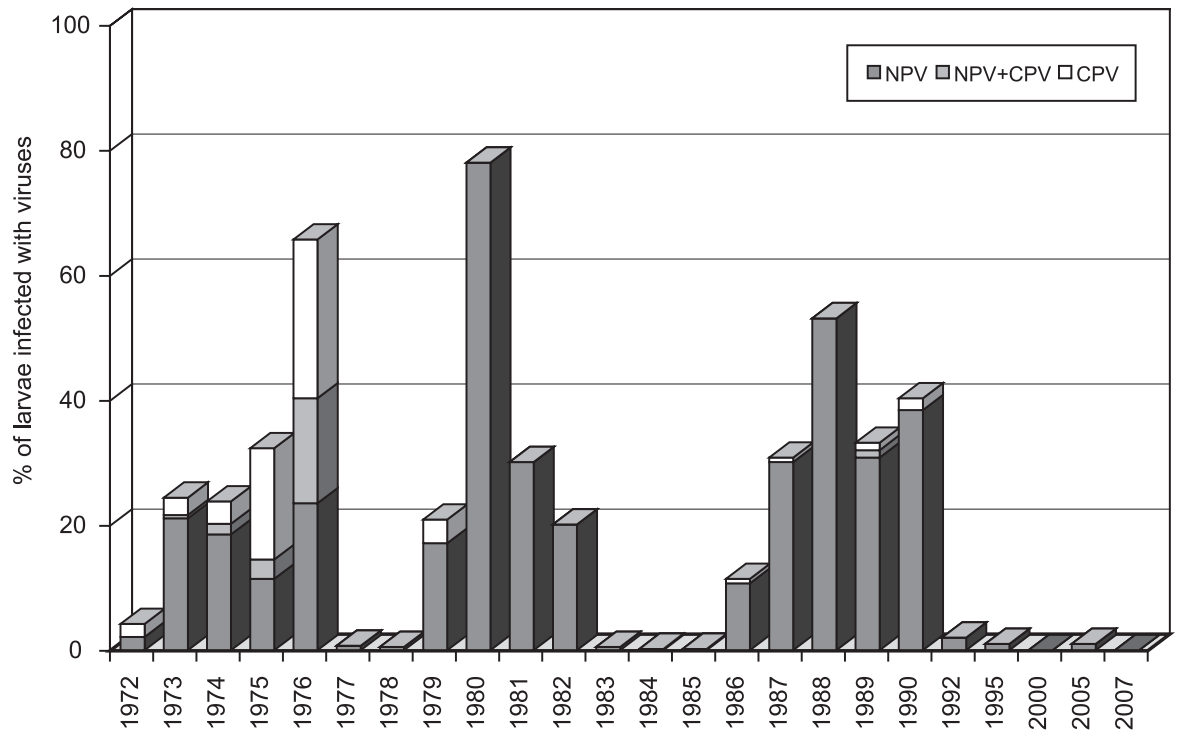

Fig. 2. Healthiness of the satin moth population (L. salicis) - "Kórnik" $\mathrm{NPV}$ - nucleopolyhedrovirus; CPV - cypovirus 
48 larvae on 10 trees). In the following years, 1973, 1974 until 1976 the population gradually increased until it reached 450 individuals; this was considered an outbreak stage (outbreak I). Records from the subsequent years revealed a decrease in number of the satin moth; the final count was 25-30 larvae. The next three years with low population density passed and a sudden outbreak of insects was observed in 1980 (3250 larvae) (outbreak II). This outbreak of the satin moth ended in 1981. However, the number of insects was only partially reduced and the population density was still high at the end (506 larvae). After four years of population decline the population density started growing again and in 1986 and 1987 there were 285 and 493 larvae. In 1988 the number of larvae was 715 (outbreak III). In two consequent years the density dropped again. In the years 1991-2007 occasional monitors showed low number of the satin moth insects (3-9 larvae on 10 trees).

Several collapses of the outbreaks in the satin moth population resulted from activity of different pathogens. They infected sensitive insects and consequently raised mortality rate within the population (Fig. 2).

Nucleopolyhedrovirus (LesaMNPV) and L. salicis cypovirus (CPV) were the main pathogens causing such a high mortality among the insects (Fig. 2). Virus CPV was present in the satin moth population during first years of the survey in "Kórnik" population. In the years 1972-1976 the infection with LesaMNPV and CPV turned to epizootic (epizootic I) and that caused a decline in population lasting three years (Fig. 1). Despite low number of insects, the viruses were present within a population. In the year 1980 another epizootic peak occurred (epizootic II; 78\% of larvae were infected with LesaMNPV) (Fig. 2). This year was also a second year of the satin moth outbreak (Fig. 1). The epizootic lasted four years. Since 1986 while the population density increased, the viral infection level raised as well. In the beginning it was fairly low; around $11 \%$ of insects were infected with NPV in 1986; then it gradually escalated. The epizootic III was recorded in 1988 (53\% of infected insects) with a population density of 715 larvae. High incidence of NPV infection (33 and 42\%) was recorded for next two years of the survey (Fig. 2). In the years 1992-2007 only single individuals with viruses were found.

The larvae collected in "Kórnik" region were also infected with bacteria from the genus Bacillus sp. and Serratia marcescens. Bacterial infections ranged from 3 to 35\% of all examined insects. High occurrences of bacterioses were recorded in the years 1972-1978. Among pathogenic fungi the most common were Aspergillus flavus Lin. Ex Fr., Beauveria bassiana (Bals.) Vuill and Fusarium sp. Link ex Fr. Nematodes from the family Mermithidae (4-6\% of insects infected) were other pests pathogenic to larvae at stage $\mathrm{L}_{5}$. The least frequent and rarely occurring were protozoa such as Plistophora sp.; $1.7 \%$ of larvae were infected.

\section{DYNAMICS AND HEALTHINESS OF INSECTS IN" KUTNO” POPULATION}

Observations of population density in Kutno region were conducted for fourteen years (1977-1990) from May $25^{\text {th }}$ to June $6^{\text {th }}$ (Fig. 3). The survey was conducted on $P$. italica trees growing near a train station in Kutno. A high density of insects occurred during first two years of the survey (1000-900 larvae per 10 trees) (outbreak I). This abundant appearance of the satin moth ceased with a 10-fold decrease of population 


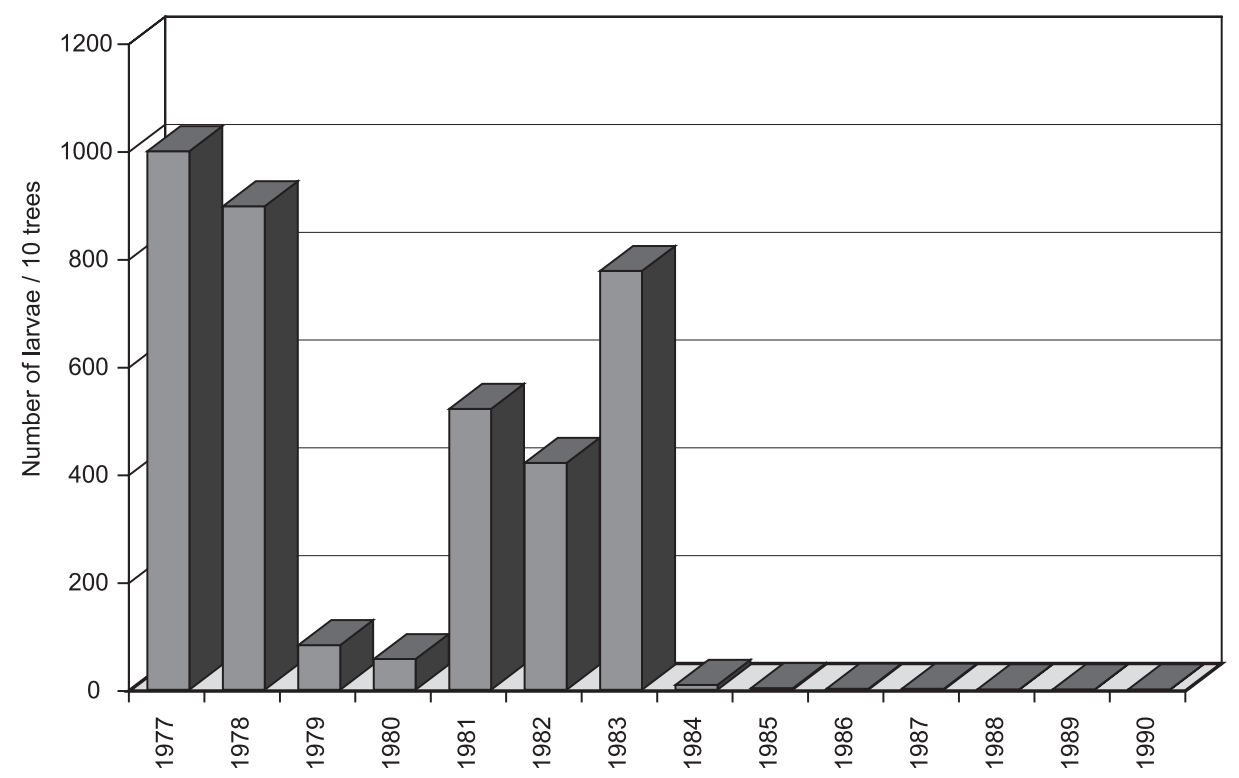

Fig. 3. Population dynamic of the satin moth (L. salicis) - "Kutno"

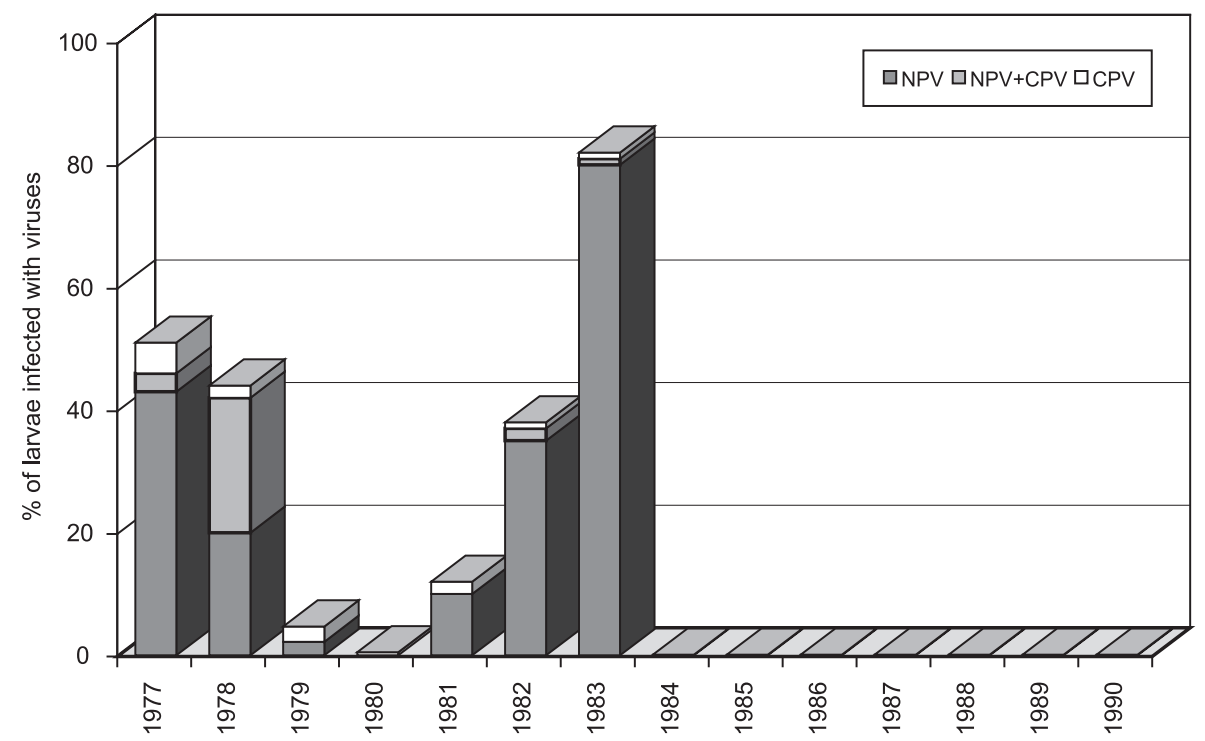

Fig. 4. Healthiness of the satin moth population (L. salicis) - "Kutno". NPV - nucleopolyhedrovirus; CPV - cypovirus. 
density in the following two years (1979-1980). The next outbreak (outbreak II) was recorded in the years 1981-1983 (778 larvae maximum). In 1994 the population density suddenly crashed and the insect incidence was at a level that did not represent a danger to trees. The number of insects was reduced approximately 80 -fold. The insects were at a depression stage and remained at that level until the end of the survey (1990). In the following year the trees were removed.

Microscopic analyses showed that $2 \%$ of larvae were infected with bacteria from the genus Bacillus sp. and 2-6\% with the fungus B. bassiana. While bacterial and fungal infections were low, a viral infection with nucleopolyhedrovirus and cypovirus appeared to be high at the time of analysis. The virus NPV was observed more frequently than CPV in 1977 (46\%), (epizootic I) (Fig. 4).

In the following year 1978 in addition to high incidence of NPV (20\%) infection with NPV + CPV (22\%) was registered. Viruses present at such a high level reduced the satin moth population drastically in the years 1979-1980 until the pest reached a depression stage. Since 1981 the viral infections among insects increased (epizootic II). An epizootic peak was recorded in 1983 when $80 \%$ of insects living in high-populated group (778 larvae) were infected with nucleopolyhedrovirus (Fig. 4). Viral infections resulted in sudden reduction of the satin moth population the following year and this phase lasted until the end of survey (1990).

\section{DYNAMICS AND HEALTHINESS OF INSECTS IN “KATOWICE "POPULATION}

Observations on population dynamics of the satin moth in Katowice were conducted for thirteen years (1973-1985), from May $21^{\text {st }}$ to June $6^{\text {th }}$. The examined P. nigra trees grew in the center of town.

In the years 1973-1975 the insect population was at a progression stage (Fig. 5). Since 1976 the population started suddenly increasing in numbers and in 1977 it reached its peak (1000 larvae) (outbreak I). In 1978 the population collapsed, and the number of insects was four times lower. In the subsequent seven years the satin moth went through a phase of three-year recession (52-24 larvae) followed by a depression stage, and it was extremely difficult to find any individuals (0-1 larva). Further surveys couldn't be conducted due to removal of the trees.

Nucleopolyhedrovirus and cypovirus dominated in the examined populations. In the years 1973-1977 (Fig. 6) they often appeared in mixed infections. In the year 1978 at the highest level of virus occurrences, only nucleopolyhedrovirus was detected (97\% larvae infected) (epizootic I). L. salicis population drastically decreased for the next seven years.

The satin moth population in "Katowice" region was infected with bacteria (3$4 \%)$, fungi (1-2\%) and protozoa (1-3\%). Among bacteria the genus Bacillus sp. dominated. S. marcescens was rarely identified. Mycoses were caused by B. bassiana. As far as protozoa were concerned, Plistophora sp. was a causal agent of infections. Ichneumonidae were the most frequent parasitoids recorded in the samples (4-6\%). 


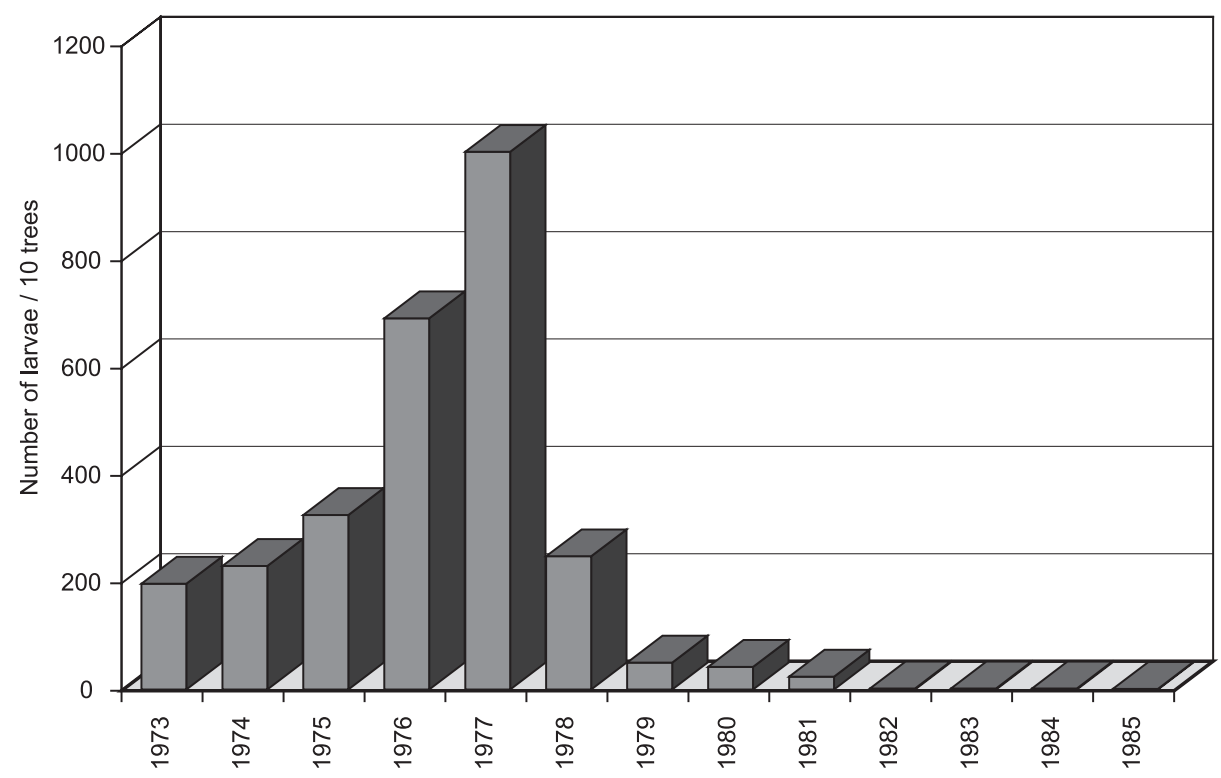

Fig. 5. Population dynamic of the satin moth (L. salicis) - "Katowice"

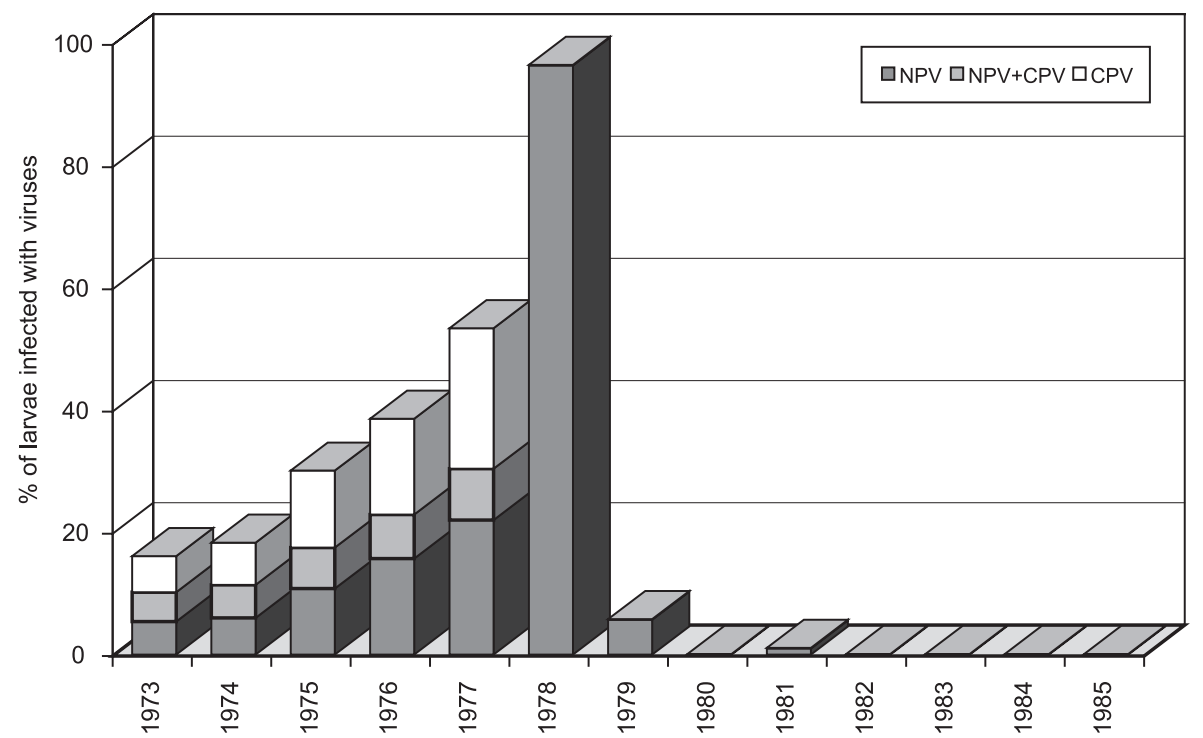

Fig. 6. Healthiness of the satin moth population (L. salicis) - "Katowice" $\mathrm{NPV}$ - nucleopolyhedrovirus; CPV - cypovirus 


\section{EFFECT OF TEMPERATURE AND RELATIVE HUMIDITY ON OUTBREAK AND EPIZOOTIC OCCURRENCES OF THE SATIN MOTH}

Analyses of correlation of outbreak and epizootic occurrences and mean temperatures and relative humidity for spring, summer months were conducted. The results are presented in Table 1 and indicate some of the relationships. Most outbreak peaks appeared in the years with warm spring, summer months with mean temperatures above $15^{\circ} \mathrm{C}$ and mean $\mathrm{RH} 50-60 \%$. Analyses of epizootic peaks showed similar relation to temperatures but RH was lower, i.e. $40-50 \%$.

Table 1. Years of occurrence of outbreak and epizootic peaks of the satin moth (L. salicis) in correlation to meteorological conditions

\begin{tabular}{|c|c|c|c|c|c|c|}
\hline \multirow{2}{*}{ Population } & \multicolumn{3}{|c|}{ Mean temperature V-VII } & \multicolumn{3}{|c|}{ Mean relative humidity V-VII } \\
\hline & $13-14^{\circ} \mathrm{C}$ & $14-15^{\circ} \mathrm{C}$ & above $15^{\circ} \mathrm{C}$ & $40-50 \%$ & $50-60 \%$ & above $60 \%$ \\
\hline \multicolumn{7}{|c|}{ OUTBREAK } \\
\hline Kórnik & 1980 & - & $\begin{array}{l}1976 \\
1988\end{array}$ & - & 1988 & 1980 \\
\hline Kutno & - & - & 1977 & - & 1977 & 1976 \\
\hline Katowice & - & - & 1977 & - & 1977 & - \\
\hline \multicolumn{7}{|c|}{ EPIZOOTIC } \\
\hline Kórnik & $1980 \mathrm{~N}$ & - & $\begin{array}{l}1976 \mathrm{NMC} \\
1988 \mathrm{~N}\end{array}$ & 1976 NMC & $1988 \mathrm{~N}$ & $1980 \mathrm{~N}$ \\
\hline Kutno & - & - & $\begin{array}{l}1977 \text { NMC } \\
1983 \text { NMC }\end{array}$ & - & $\begin{array}{l}1977 \text { NMC } \\
1983 \text { NMC }\end{array}$ & - \\
\hline Katowice & - & $1978 \mathrm{~N}$ & - & - & $1978 \mathrm{~N}$ & - \\
\hline
\end{tabular}

$\mathrm{N}$ - NPV (nucleopolyhedrovirus); C - CPV (cypovirus); $\mathrm{M}-\mathrm{NPV}+\mathrm{CPV}$.

Bold letters indicate patogen dominating in the population

\section{DISCUSSION}

Outbreaks of the satin moth and viral epizootics were observed in numerous European and other continents countries but knowledge about them is scarce. The literature refers mostly to their incidental occurrence in different environments. Longterm survey on the same population of the satin moth allowed to understand better these phenomena and a relation host-pathogen under conditions of low and high density, also at different infection severity, and various temperatures and humidity. Outbreaks and epizootics shared some similarities in examined regions. They displayed similar rhythm, orders of particular stages, and periods of their increases, peaks and declines.

Duration of particular stages differed in each monitored population. There were some concerns not only about length of outbreaks and epizootics within the same population but also effect of pollution on insects in examined areas. Some authors indicated (Price et al. 1974; Chłodny 1980) that pollution is usually more harmful to 
predatory and parasitic insects. Lepidoptera and Homoptera insects demonstrate high tolerance to polluted environment (Villemant 1980; Migula 1984). Migula (1985) revealed that mortality of L. salicis and Euproctis chrysorrhoea increased with toxin accumulation in the surroundings, particularly $\mathrm{SO}_{2}$ and acid rain. However, direct effect of dust pollution was small. Long hairs covering larva bodies protected insects from dust contact. As far as pupae were concerned and dust pollution, the pupal bodies were protected with strong cocoon that developed during pupating. Because of better mechanism of cell regulation the satin moth demonstrated better response to environment stress than E. chrysorrhoea. This behavior is typical for the insects living for many generations under high pollution pressure in particular environment (Migula 1985). High tolerance to environment conditions allows the insects to spread out easily into large areas.

In "Kórnik" population there were three outbreaks over nineteen years and lasted four, two and three years. The periods between the outbreaks with low insect densities were two and three years. In "Kutno" during fourteen-year observations the outbreak lasted seven years. In "Katowice" population there was a five-year outbreak.

In the mid 1950s Schnaiderowa (1959) observed the outbreak of satin moth on poplar trees. The outbreaks lasting from two to seven years and longer were observed also in other countries. Jahn and Sinreich (1965) described two-year outbreak in Austria. Three-year outbreaks were documented in Belgium (Nef 1976) Bulgaria (Zakharieva 1983a) and Hungary (Abraham 1996). The outbreaks lasting four years were observed on poplars in western Siberia (Kolomiec 1971), in Altai region, Russia (Dondikov 1974), Tomsk region, Russia (Nikiforov 1979) and Turkey (Cobanoglu 1992). Seven-year outbreaks were recorded in Belgium (Nef 1975). The outbreaks of satin moth in Siberia were ten-eleven years lasting (Galkin 1975). Long-term outbreaks were often caused by both low level of predators and parasitoids or lack and low level of entomopathogens within pest population. Polluted air in Katowice area did not favor development of entomophages, as we can assume low temperatures in Siberia did either.

All observed outbreaks fluctuated similarly. Outbreak rhythm was dependent upon virus type and its abundance within insect population. Abundant insect populations with high concentration of a virus collapsed rapidly. It was observed in "Kórnik" region where both virus nucleopolyhedrovirus and cypovirus reduced $L$. salicis numbers to a level of depression. Presence of both viruses NPV and CPV at the same time was conducive to development of mixed infection in the insects. The laboratory experiments showed that inoculum of NPV and CPV placed in food for larvae L. salicis caused synergistic effect (Ziemnicka 1981). It resulted in several times higher mortality rate. L. salicis cypovirus occurred less frequently than nucleopolyhedrovirus did. NPV virus domination was observed in mixed populations also in the next two outbreaks.

L. salicis NPV virus is very aggressive towards its hosts. Some Polish strains are several times more virulent compare to others with different origin. Higher virulence of NPV was confirmed in an assay comparing Polish strains with Yugoslavian (Lameris et al. 1985). Dominating role of NPV in biological control was observed in all outbreaks of the satin moth in Poland (Schnaiderowa 1959; Ziemnicka 1976a, b, 1981) and other countries as well (Weiser et al. 1954; Huertos and Templado 1958; Grigorova 1962; Orlovskaya 1968; Sidor et al. 1978; Maksymov 1978; Grijpma 1989). Similar 
domination and high efficiency of NPV was also recorded in the second outbreak in "Kutno" and "Katowice".

Domination of CPV did not decrease population density of the satin moth. Sudden decline within the insect population was recorded upon appearance of NPV that reduced the number of insects to a depression level. Epizootics caused by CPV do not occur frequently. CPV epizootic in the satin moth population was observed only once in Austria in the years 1962-1963 (Jahn and Sinreich 1965). However, it doesn't prove that CPV virus does not infect the satin moth population, what was showed in the bibliographic study (Ziemnicka 1976b; Ziemnicka 1981). CPV virus belongs to the family Reoviridae, genus Cypoviruses the differ with NPV virus not only in the genome and also in biological activity. Reoviridae viruses are less aggressive compared to viruses from the Baculoviridae family. CPV has a RNA genome and replicates in the cytoplasm of the infected cells while NPV has a DNA genome and replicates in the nucleus. Replication of the CPV virus is only confined to midgut epithelial cells, which have a great regeneration potential (Yamaguchi 1977).

Other natural enemies of the satin moth such as bacteria, fungi and parasitoids occurred in small quantities and did not affect outbreak and epizootic cycles in examined regions. Nonthless, they might play an important role in other populations of that insect species. Entomopathogenic fungi B. bassiana, Fusarium sp., Paecilomyces sp. and Hirsutella gigantea (Ogarkov and Ogarkova 1979; Wagner and Leonard 1980; Ziemnicka and Sosnowska 1996) caused several-year epizootics decreasing efficiently the insect population. Telenomus nitidulus (Hymenoptera), an egg parasite of the satin moth played an important role in decreasing density of the stain moth population (Dondikov 1974; Nef 1976; Teodorescu 1980; Zakharieva 1983b, Grijpma and Van Lenteren 1988) as well as larval parasites Meteorus versicolor and Rogas spp. (Obozov 1968; Maksymov 1978; Grijpma 1989). Parasitoid insects do not only reduce a number of insects but also act as vectors spreading out the viruses (Ziemnicka et al. 1996).

Temperature and humidity are significant abiotic elements responsible for proper metabolism of insect hosts. They can also affect the antagonists of the pests. Numerous observations showed that high temperatures were recorded prior mass occurrence of the insects (Maksymov 1978). Analyses of meteorological data for the investigated regions did not show the differences in temperatures and humidity of the years before and during the outbreaks and epizootics. There was no influence of temperature and humidity on initiation and duration of the outbreaks as well. However, years of outbreak peaks showed some relationship with temperatures and humidity range. Most happened at temperatures above $15^{\circ} \mathrm{C}$ and $50-60 \% \mathrm{RH}$. It indicates that warm and humid weather favors replication of the satin moth.

High temperatures were also conducive to years of epizootic peaks but humidity range was lower (40-50\%). It indicates that warm and dry weather in spring and summer months is more favorable to development of viruses. These conditions affect negatively parasitoids and a host. Lack of food occurring during outbreaks and its low nutritional value increase the host sensitivity to viral infections. As it was observed mean monthly temperatures above $15^{\circ} \mathrm{C}$ in spring and summer favored a development of NPV and mixed infection of NPV and CPV, while below $13-14^{\circ} \mathrm{C}$ only NPV. Similar correlations were found in Macedonia (Kuševska 1972). 


\section{CONCLUSIONS}

1. Nucleopolyhedrovirus LesaMNPV is the most efficient biological control of the satin moth (Leucoma salicis) in regions of its common occurrence.

2. Natural epizootics occur in populations of high density and severe incidence of nuclear polyhedrosis viral infection.

3. Mean monthly temperatures above $15^{\circ} \mathrm{C}$ in spring, summer months, and relative humidity $50-60 \%$ are favorable to the occurrence of outbreak peaks.

4. Mean monthly temperatures above $15^{\circ} \mathrm{C}$ in spring, summer months, and relative humidity $40-50 \%$ are favorable to the occurrence of epizootic peaks.

\section{ACNOWLEDGEMENTS}

I want to thank Prof. Stanisław Bałazy from the Research Center for Agricultural and Forest Environment Polish Academy of Sciences, Poznań for assistance in identification of entomophagous fungi and the colleagues from the Institute of Plant Protection in Poznan and the Plant Health and Seed Inspections for help in collecting the insect material.

\section{REFERENCES}

Abraham G. 1996. The mass appearance of willow tussock moth (Stilpnotia salicis L) in Gyor - Sopron County. Novenyvedelem 32 (5): 247-248.

Arru G.M. 1975. Annotated list of the most important insects injurious to the cultivation of poplar in Italy. Cellulosa-e-carta 26 (11): 47-50.

Avtzis N.D. 1990. Development of Leucoma salicis (L.) (Lepidoptera: Lymantriidae) on Populus alba (L.) and poplar clone I-214. Entomologica-Hellenica 8: 25-27.

Chen L.S. 1984. A note on nuclear polyhedrosis virus of Stilpnotia salicis. Forest Science and Technology Linye Keji Tongxun 12: 27-28.

Chen Y.X., Zhang X.T., Zhou F.C., Yang Y.S., Gao Y.G., Zhao W.Y. 1990. Studies on damage index of five foliar pests of poplars. Forest Pest and Disease 1: 17-20.

Chłodny J. 1980. Wpływ na entomofaunę leśną. p. 242-259. W: „Siarka w biosferze” (J. Siuta, M. Rejman-Czajkowska wyd.). PWRiL, Warszawa.

Clarke L.J., Pardy K.E. 1971. Biological control of the satin moth in Newfoundland. Bi-month. Res. Note, Can. Fish. For. 26: 36-37.

Cobanoglu S. 1992. Studies on the distribution and biology of the satin moth, Leucoma salicis (L.) (Lep., Lymantriidae) harmful to poplar trees in Edirne province. p. 571-583. Proceedings of the Second Turkish National Congress of Entomology. Izmir, Turkey, Ege Universitesi.

De Hoog G.S. 1972. The genera Beauveria, Isaria, Tritirachium and Acrodontium. Stud. Mycol. 1: 1-44.

Dondikov N.M. 1974. Stilpnotia salicis in the Altai region. [in Russian]. Zashch. Rast. 9: 47.

Doom D. 1979. Damage by insects and mites to trees and shrubs in 1978. Nederlands Bosbouw Tijdschrift 51 (5/6): 149-158.

Drea J.J., Gruber F., Fuester R.W., Mercadier G., Hoyer H. 1977. Observations on Hexamermis albicans (Nematoda: Mermithidae) recovered from Lymantria dispar and Stilpnotia salicis (Lep.: Lymantriidae) in West Germany and Austria. Entomophaga 22 (2): 141-146.

Ěvlachova A.A., Švecova O.J. 1964. Metody rozpoznavanija bolezniej nasiekomych. [in Russian]. Ministerstwo Selskovo Chozjajstwa SSSR: 32-33. 
Furniss R.L. 1939. Insects attacking forest products and shade trees in Washington and Oregon in 1937. Proc. Ent. Soc. Brit. Columbia 25: 5-8.

Galkin G.J. 1975. Outbreaks of Dendrolimus sibericus and solar activity. [in Russian]. Lesn. Khoz. 8: 83-85.

Gams W. 1971. Cephalosporium - artige Schimmelpilze (Hyphomycetes). G. Fisher. Stuttgart, 261 pp.

Grigorova R. 1962. On nuclear polyhedrosis of the satin moth (Stilpnotia salicis L.). Comptes Rendus de l'Academie Bulgarie des Sciences 15 (1): 85-88.

Grijpma P.J. 1989. Overview of research on Lymantriids in Eastern and Western Europe. p. 21-49. In: Proceedings „Lymantriidae: A Comparison of Features of New and Old World Tussock Moth" (W.E. Wallner and K.A. McManus, eds.). USDA, NEFS. Gen. Tech. Report NE-123, Broomal, (US), $554 \mathrm{pp}$.

Grijpma P., Persoons C.J., Peters D., Vlak J.M. 1986. Biological control of satin moth with pheromones and baculoviruses. Project Report 1985. European Economic Community; Rand D Programme: Wood as a renewable row material., Wageningen, Dorschkamp Rapport 443, 19 pp.

Grijpma P., Van Lenteren J.C., 1988. Telenomus nitidulus (Hymenoptera: Scelionidae), egg parasite of the satin moth Leucoma salicis (Lepidoptera: Lymantriidae). In: „Trichogramma and Other Egg Parasites". Inst. Nat. Res. Agron., Paris. Les Colloques de l'INRA 43: 181-189.

Gromova A.A. 1980. The willow lymantriid. [in Russian]. Zashch. Rast. 9: 50.

Harrigan W.F., McCance M.E. 1966. Laboratory methods in microbiology. Academic Press London and New York, $362 \mathrm{pp}$.

Huertos R.M., Templado J. 1958. Un virus poliedrico en Stilnotia salicis (L.) (Lepidoptera, Lymantriidae). [in Spanish]. Microbiologia Española 11: 93-98.

Jahn E., Sinreich A. 1965. Beobachtungen zur Massen vermehrung des Weidenoder Pappelspinners, Stilpnotia salicis L. in Windschutzstreifen im Seewinkel des Burgenlandes in den Jahren 1962 und 1963, Anz. Schädlingskunde 38: 17-23.

Kailidis D.S. 1964. Epidemic tes Stilpnotia salicis L. (Lepidoptera, Lymantriidae) kata to 1964 ton aeykon en Makedonia. Dasika Chron. Athenai 6 (11/12): 41-50.

Kolomiec N.G. 1971. Estestvennye vragi ivovoj volnjanki v zapadnosibirskoj nizmennosti. [in Russian]. Izv. Sib.Otd. Akad. Nauk. SSSR Biol. Nauk 10 (2): 102-109.

Kuševska M. 1972. The influence of ecological conditions on the occurrence and development of polyhedrosis in larvae of Stilpnotia salicis L. Fragmenta Balcanica 9 (2): 9-19.

Lameris A.M.C., Ziemnicka J., Peters D., Grijpma P., Vlak J.M. 1985. Potential of baculoviruses for control of the satin moth, Leucoma salicis L. (Lepidoptera: Lymantriidae). Med. Fac Landbouww. Rijksuniv. Gent. 50 (2a): 431-439.

Lejeune R.R., Silver G.T. 1961. Parasites and hyperparasites of the satin moth, Stilpnotia salicis Linnaeus, (Lymantriidae) in British Columbia. Canad. Entomol. 93 (6): 456-467.

Lipa J.J. 1967. Zarys Patologii Owadów. PWRiL, Warszawa, 364 pp.

Lipa J.J. 1996. Present status of noxious Lymantriidae in Europa and Poland. p.127-136. In: Proceedings of the International Conference „Integrated Management of Forest Lymantriidae” March 27-29,1996. Warsaw-Sękocin, Poland.

Lipa J.J., Głowacka B. 1996. Nun moth (Lymantria monacha L.) in Europe and Poland. p. 138-158. In: Proceed. Annual Gypsy Moth Review, Nov. 5-8, 1995, Traverse City, USA.

Lipa J.J., Kolk A. 1995. The recent situation of the gypsy moth (Lymantria dispar) and other lymantriids in Poland. OEPP/EPPO Bulletin 25: 623-629.

Lipa J.J., Ziemnicka J. 1996. Spiroplasma and microsporidian infections in populations of Leucoma salicis L. (Lepidoptera: Lymantriidae) in Poland. p.123-126. In: Proceedings of International Con- 
ference „Integrated Management of Forest Lymantriidae”. 27-29 March 1996, Warsaw-Sękocin, Poland.

Lipa J.J., Ziemnicka J., Gazecka B., Korytek L. 1988. A newly recorded Spiroplasma infection in Stilpnotia salicis L. (Lepidoptera, Lymantriidae). Prace Nauk. Inst. Ochr. Roślin 30 (1-2): 15-19.

Luitjes J. 1973. The effect of defoliation by Leucoma salicis on the growth of poplar. [in Dutch]. Ned. Bosb. Tijdschr. 45 (2): 45-53.

Maksymov J.K. 1978. Die Massenvermehrung des Pappelspinners Stilpnotia salicis L. (Lep., Lymantriidae) in der Orbe-Ebene. Schweiz. Z. Forstw., 129, 5: 424-430.

Marikovskij P.N. 1977. A mass outbreak of the satin moth. [in Russian]. Zashch. Rast. 9: 29.

Migula P. 1984. Wrażliwość niektórych Lepidoptera na zanieczyszczenia powietrza gazami i pyłami przemysłowymi. [in Polish]. Abstr. XVI Congr. Pol. Physiol. Soc., Katowice, p. 251.

Migula P. 1985. Wrażliwość wybranych gatunków owadów na skażenia powietrza gazami i pyłami przemysłowymi oraz tolerancja przez nie termicznych zmian środowiska. [in Polish]. Prace Nauk. Uniw. Śląsk. Katowice 765, 115 pp.

Nef L. 1975. Etude ecologique des pontes de Stilpnotia (=Leucoma) salicis L. Ann. Soc. Roy. Zool. Belg. 105: 129-146.

Nef L. 1976. Etude ecologique de Telenomus nitidulus, parasite des oeufs de Stilpnotia (Leucoma) salicis L. J. Plant Dis. Protect. 83: 109-119.

Nikiforov G.M. 1979. Leucoma salicis, a pest of the tayga forests in the Tomsk region. [in Russian]. Lesn. Khoz. 8: 66-67.

Obozov A.N. 1968. The white satin moth. [in Russian]. Zashch. Rast.13 (9): 46.

Ogarkov B.N., Ogarkova G.R. 1979. Fungal epizootics of insect pests in the Irkutsk region. Mikol. Fitopatol. 13 (1): 10-12.

Orlovskaya E.V. 1968. Vospriimčivost nekotorych vidov dendrofilnych česeukrylych k rozličnym virusam. Zashch. Lesa 1 (115): 170-182.

Ortiz E., Templado J. 1973. The chromosomes of four species of Lymantriidae (Lepidoptera). Eos. 49 (1/4): 225-232.

Poinar G.O. 1975. Entomogenous nematodes. A manual and host list of insect-nematode associations. E.J. Brill, Leiden, Netherlands, 317 pp.

Price P.W., Rathcke B.J., Gentry D.A. 1974. Lead in terrestrial arthropods: evidence for biological concentration. Environ. Entomol. 3: 370-372.

Reeks W.A., Smith C.C. 1956. The satin moth, Stilpnotia salicis (L.), in the Maritime Provinces and observations on its control by parasites and spraying. Can. Ent. 88: 565-579.

Samson R.A. 1974. Paecilomyces and some allied Hyphomycetes. Stud. Mycol. 6: 1-119.

Schnaiderowa J. 1959. Z badań nad białką wierzbówką. [in Polish]. Prace Inst. Bad. Leśn. 189: 19-62.

Schoenherr J. 1989. Outbreak characteristics of Lymantriids. p. 171-181. In: „Proceedings, Lymantriidae: A Comparison of Features of New and Old World Tussock Moths" (W.E. Wallner, K.A. McManus, eds.) USDA, NEFS. Gen. Tech. Report NE-123, Broomal (US), 554 pp.

Serafimovski A. 1972. Biological and ecological studies of the satin moth (Stilpnotia salicis L.). Godisnik, Sumarski Instytut - Skopje 7: 5-105.

Schaefer P.W. 1989. Diversity in form, function, behaviour, and ecology: an overview of the Lymantriidae (Lepidoptera) of the World. p.1-19. In: Proceedings „Lymantriidae: A Comparison of Features of New and Old World Tussock Moths" (W.E. Wallner and K.A. McManus, eds). USDA, NEFS. Gen. Tech. Rep. NE-123, Broomal, (US), 554 pp.

Sidor C. 1976. Diseases caused by microorganismus in some species of Lymantriidae in Yugoslavia and their importance to the entomofauna. [in Serbian]. Archiv. Bioloskih Nauke 28 (3/4): 127-137. 
Sidor C., Zamola B., Kajfez J.F. 1978. Polyhedral viral disease of Leucoma salicis L. in Voivodina, Yugoslavia. [in Serbian]. Archiv za Higijenu Rada i Toksikologiju 29: 219-233.

Sirota Y., Ueda K., Kuwana Y., Komai F. 1976. Biological studies on Leucoma candida (Staudinger) (Lepidoptera, Lymantriidae) in Japan. I. Biology and life history. Kontyu. 44 (1): 85-92.

Skatula U. 1985. Untersuchungen zur Wirkung eines Kernpolyhedrevirus aus Leucoma salicis (Lep., Lymantriidae) auf einige Lymantriiden-Arten. Anz. Für Schaendlings.Phlanzenschutz, Umweltschutz 58: 41-47.

Teodorescu J. 1980. Contribution of the oophagus Scelionids (Proctotrupoidea - Scelionidae) to the limitation of attack by some defoliating Lepidoptera. [in Roumanian]. Stud. Cercet. Biol., Biol. Anim. 32 (2): 177-180.

Villemant C. 1980. Influence de la pollution atmospherique sur les microlepidopteres du pin eu foret du Roumaire (Seine-Maritime). Acta Ecol. 1 (4): 291-306.

Wagner T.L., Leonard D.E. 1979. The effects of parental and progeny diet on development, weight gain and survival of prediapause larvae of satin moth, Leucoma salicis (Lepidoptera: Lymantriidae). Can. Ent. 111: 721-729.

Wagner T.L., Leonard D.E. 1980. Mortality factors of satin moth Leucoma salicis (Lep.: Lymantriidae) in aspen forests in Maine. Entomophaga 25: 7-16.

Wallner W.E. 1988. An overview of pest Lymantriids of North America. p. 65-80. In: Proceedings „Lymantriidae: A Comparison of Features of New and Old World Tussock Moths" (W.E. Wallner and K.A. McManus, eds.). USDA, NEFS. Gen. Tech. Report NE-123, Broomal (US), 554 pp.

Weiser J., Ludvik J., Veber J. 1954. Polyedrie bekyne vbrově (Stilpnotia salicis L., Lepidoptera). Zool. Entomol. Listy 4: 238-242.

Yamaguchi K. 1977. Regenaration of the midgut epithelial cells in the silkworm, Bombyx mori, infected with the cytoplasmic polyhedrosis virus. J. Sericult. Sci. Japan 46: 179-180.

Zakharieva A. 1983a. The phenology of Stilpnotia salicis in the Sofia and Burgas regions. [in Bulgarian]. Gorsko-Stopanstvo 39: 35-37.

Zakharieva A. 1983b. Species composition and role of parasites of L. in Bulgaria. [in Bulgarian]. Nauchni Tr. Vissh Lesotekh. Inst. Sofiya, Ozelenyavane 27/28: 107-113.

Zakharieva-Pentcheva A., Georgiev G.T. 1997. Parasitoids of the satin moth Stilpnotia salicis (L.) (Lepidoptera, Lymantriidae) in Bulgaria. [in Bulgarian]. Bolle. Zool. Agr. Bach. 29 (1): 81-90.

Ziemnicka J. 1976a. Białka wierzbówka - groźny szkodnik wierzb i topól. [in Polish]. Ochrona Roślin 5: 17-18.

Ziemnicka J. 1976b. A note on the cytoplasmic polyhedrosis virus of the satin moth Stilpnotia salicis L. (Lepidoptera, Lymantriidae). Bull. Acad. Pol. Sci., Biol. Cl. V. 24 (8): 461-462.

Ziemnicka J. 1981. Studies on nuclear and cytoplasmic polyhedrosis viruses of the satin moth (Stilpnotia salicis L.) (Lepidoptera, Lymantriidae). Prace Nauk. Inst. Ochr. Roślin 23 (1): 75-142.

Ziemnicka J., Hilszczański J., Bystrowski C. 1996. Occurence of viruses and parasitoids in natural populations of satin moth Stilpnotia salicis L. (Lepidoptera: Lymantriidae). p. 127-136. In: Proceedings of International Conference „Integrated Management of Forest Lymantriidae” 27-29 March 1996, Warsaw - Sękocin, Poland.

Ziemnicka J., Sosnowska D. 1996. Entomopathogenic fungi in population of the satin moth Stilpnotia salicis L. J. Plant Prot. Res. 37 (1/2): 128-137. 


\section{POLISH SUMMARY}

\section{GRADACJE I NATURALNE EPIZOOCJE WIRUSOWE BIAŁKI WIERZBÓWKI LEUCOMA SALICIS L. (LEPIDOPTERA: LYMANTRIIDAE)}

Podczas wieloletnich badań populacji białki wierzbówki Leucoma salicis stwierdzono występowanie licznych ognisk gradacyjnych i naturalnych epizoocji wirusowych. Liczba owadów w ogniskach gradacyjnych w fazie kulminacji wyniosła od 450 do 3250 na 10 topolach doświadczalnych (do 2 m wysokości pnia). Poziom wirusów w populacjach o takim zagęszczeniu rósł wraz ze wzrostem liczebności owadów. Gwałtownemu załamaniu ulegały populacje silnie zagęszczone o wysokim poziomie nukleopoliedrowirusa i cypowirusa.

Gradacjom białki sprzyjały ciepłe i wilgotne, natomiast epizoocjom wirusowym ciepłe i suche miesiące wiosenno-letnie. Większość kulminacji gradacyjnych miała miejsce w latach o średnich temperaturach miesięcy wiosenno-letnich wyższych od $15^{\circ} \mathrm{C}$ i przy $50-60 \%$ średniej wilgotności względnej powietrza. Większość kulminacji epizootycznych występowało w warunkach o podobnej temperaturze lecz niższej wilgotności względnej powietrza (40-50\%). 